Review

\title{
Cytokine Release Syndrome in the Immunotherapy of Hematological Malignancies: The Biology behind and Possible Clinical Consequences
}

\author{
Tor Henrik Anderson Tvedt ${ }^{1}$, Anh Khoi Vo ${ }^{2}$, Øystein Bruserud ${ }^{2,3}$ and Håkon Reikvam ${ }^{2,3, *}$ \\ 1 Department of Hematology, Oslo University Hospital, 0372 Oslo, Norway; Totvedt@ous-hf.no \\ 2 Department of Clinical Science, University of Bergen, 5020 Bergen, Norway; \\ anh.khoi.vo@helse-bergen.no (A.K.V.); oystein.bruserud@helse-bergen.no (Ø.B.) \\ 3 Clinic for Medicine, Haukeland University Hospital, 5020 Bergen, Norway \\ * Correspondence: Hakon.Reikvam@med.uib.no
}

check for updates

Citation: Tvedt, T.H.A.; Vo, A.K.; Bruserud, Ø.; Reikvam, H. Cytokine Release Syndrome in the

Immunotherapy of Hematological Malignancies: The Biology behind and Possible Clinical Consequences. J. Clin. Med. 2021, 10, 5190. https:// doi.org/10.3390/jcm10215190

Academic Editors: Pietro Merli and Lucia Prezioso

Received: 5 October 2021

Accepted: 3 November 2021

Published: 6 November 2021

Publisher's Note: MDPI stays neutral with regard to jurisdictional claims in published maps and institutional affiliations.

Copyright: (c) 2021 by the authors. Licensee MDPI, Basel, Switzerland. This article is an open access article distributed under the terms and conditions of the Creative Commons Attribution (CC BY) license (https:/ / creativecommons.org/licenses/by/ $4.0 /)$.

\begin{abstract}
Cytokine release syndrome (CRS) is an acute systemic inflammatory syndrome characterized by fever and multiple organ dysfunction associated with (i) chimeric antigen receptor (CAR)-T cell therapy, (ii) therapeutic antibodies, and (iii) haploidentical allogeneic stem cell transplantation (haplo-allo-HSCT). Severe CRS can be life-threatening in some cases and requires prompt management of those toxicities and is still a great challenge for physicians. The pathophysiology of CRS is still not fully understood, which also applies to the identifications of predictive biomarkers that can forecast these features in advance. However, a broad range of cytokines are involved in the dynamics of CRS. Treatment approaches include both broad spectrum of immunosuppressant, such as corticosteroids, as well as more specific inhibition of cytokine release. In the present manuscript we will try to review an update regarding pathophysiology, etiology, diagnostics, and therapeutic options for this serious complication.
\end{abstract}

Keywords: cytokines; chimeric antigen receptor; therapeutic antibodies; haploidentical allogeneic stem cell transplantation

\section{Introduction}

Cytokine release syndrome (CRS) was first described in the late 1980s as a systemic inflammatory response following treatment with anti-CD3 monoclonal antibody for graft rejection after solid organ transplants [1]. Initially used interchangeably with cytokine storm, a much broader term describing hyperinflammation caused by a large variety of disorders [2], CRS now refers to the immunological phenomenon triggered by immunotherapy such as, chimeric antigen receptor (CAR)-T cells [3], bi-specific T cell engagers (BiTEs) [4], or haploidentical allogeneic hematopoietic stem cell transplantation (haplo-allo-HSCT). However, as discussed in detail in a recent review there are many similarities between CRS secondary to these immunotherapeutic interventions and the COVID-19-associated cytokine storm syndrome; these authors therefore suggested that one should use the knowledge from the hematological CRS as a guideline for further studies, including clinical trials, in other cytokine storm syndrome, especially patients with critical severe acute respiratory syndrome coronavirus-2 (SARS-CoV-2) infections / coronavirus disease of 2019 (COVID19) [5]. In the current article, we discuss etiology, pathophysiology, clinical manifestation, diagnostic approaches, and treatment modalities regarding CRS.

\section{CRS Etiology}

\subsection{CRS Following CAR-T Cell Therapy}

Treatment with tumor-antigen specific T cells genetically engineered to express CARs is highly effective in different cancers and has been approved in treatment of relapsed/refractory 
B-cell malignancies, including acute lymphoblastic leukemia (ALL) and multiple myeloma (MM). However, this approach can also result in severe toxicities that are directly linked to the induction of the potent immune effector responses. The massive cytokine release is believed to be caused both by the CAR-T cells themselves, bystander immune cells such as macrophages, as well as the tumor cells and their neighboring stromal cells. Several factors influence the severity of CRS. Firstly, a high number of infused T cells and the quality of the T cells significantly increase the risk of severe CRS $[3,6]$. Secondly, a high tumor burden may result in a significant degree of T cell activation and CRS $[3,6]$. Thirdly, to ensure adequate proliferation and maintenance of CAR-T cell must the CAR construct contain a contain co-stimulatory intracellular signaling domains CAR- T cells construct. Constructs utilizing, CD28 co-stimulatory domains have a higher risk of CRS than 4-1BB domain constructs; probably due to lower peak levels of $\mathrm{T}$ cell proliferation [7]. The risk of CRS also varies between different disorders and patients' characteristics; with a significant higher incidence of CRS observed in patients with ALL compared with MM, and higher incidence of severe CRS in elderly patients compared with younger patients.

\subsection{CRS Following Antibody Treatment}

Monoclonal antibodies that directly target $\mathrm{T}$ cells carry the highest risk of severe CRS. This is illustrated by the phase I clinical trial of the CD28-targeting TGN1412 monoclonal antibody [8], where six healthy volunteers experienced severe CRS requiring intensive care treatment within few hours for participants [8]. Other monoclonal antibodies associated with high risk of CRS are the CD3-targeting moruomab and basiliximab, in addition to daclizumab that target the IL-2 receptor (CD25) [9-12].

A specific form of antibody therapy is treatment with bispecific monoclonal antibodies. Bispecific monoclonal antibodies are proteins containing two antigen binding domains, one that targes tumor cells and a second antigen binding domain that target $\mathrm{T}$ cells. This ensures tumor recognition by T-cell, T-cell activation, proliferation, and T cell mediated cytotoxicity. Currently have only a few BiTEs have been approved, e.g., blinatumumab for ALL, although several are in development, e.g., mosunetuzumab for follicular lymphoma (FL). While treatment with blinatumumab is associated with a high risk of CRS, this does not seem to be true for BiTEs for other hematological malignancies.

Alemtuzumab is a monoclonal antibiotic that targets CD52 expressed by lymphocytes, monocytes, and dendritic cells [13]. Intravenous administration is associated with a high frequency of immediate toxicity mainly related to first-dose reactions, including fever, rigor, and skin rash. However, subcutaneous administration is generally well tolerated with significantly lower risk of CRS. The first dose of alemtuzumab in transplant conditioning is usually administered as a full intravenous dose of $20 \mathrm{mg}$ together with steroid prophylaxis, in contrast to the dose-escalation schemes often followed in chronic lymphocytic leukemia (CLL) treatment. Even though the subcutaneous route is associated with a better safety profile it is rarely used in graft versus host (GVHD) prophylaxis.

\subsection{CRS and Anti-Thymocyte Globulin}

Anti-thymocyte globulin (ATG) is currently wildly used as GVHD prophylaxis [14], and CRS has been reported for patients receiving ATG infusion [15]. ATG is a polyclonal antibody preparation derived either from horse or rabbit immunized with human thymocytes or the human Jurkat T cell leukemia cell line. Mild infusion-related reactions are frequent, but severe CRS, however, still self-limiting, can also be observed. Infusion-related reactions can be associated with a large variety of acute and delayed immunological reactions. Although the various ATG products currently used differ regarding antigen specificity, all products target antigens expressed on T cells, B-cells, macrophages, and antigen presenting cells as well as proinflammatory cytokines. 


\subsection{CRS Following Haploidentical Allogeneic Stem Cell Transplant}

Haplo-allo-HSCT is a form of allo-HSCT where the donor only shares one human leukocyte antigen (HLA) haplotype with the recipient and is mismatched for a variable number of HLA genes. This significant HLA mismatch results in an early and excessive activation of alloreactive $T$ cells that would result in severe and fatal GVHD without adequate measures [16-19]. The most frequently used protocol to ameliorate the HLA disparity is administration of two doses of cyclophosphamide between Day 3 and 5 posttransplant [16]. Posttransplant cyclophosphamide results in a targeted destruction of alloreactive $\mathrm{T}$ cells, while spearing the graft versus leukemia reactivity and $\mathrm{T}$ cells responsible for viral immunity.

There is a significant risk of CRS for haploidentical transplantation utilizing $\mathrm{T}$ cell repleted granulocyte colony- stimulating factor (G-CSF) mobilized peripheral blood stem cell grafts [20]. CRS usually occurs during the first posttransplant days prior to administration of cyclophosphamide and typically manifests with fever. This is possibly caused by rapidly proliferating alloreactive $\mathrm{T}$ cells, and it resolves upon administration of cyclophosphamide. Most cases are mild and administration of acetaminophen, in addition to cyclophosphamide, is usually sufficient to control the symptoms. Abboud et al. reported that the overall incidence of severe CRS (i.e., Grade 3 or 4 ) was less than $15 \%$ and with some patients experiencing mild neurological symptoms or reduction in left ventricular functions [21]. A significant increase in interleukin (IL)-6 levels experiencing CRS, and all patients experiencing severe CRS responded within $48 \mathrm{~h}$ after administration of tocilizumab. Although CRS resolved quickly, long term survival due to treatment-related mortality was significantly higher in patients that experienced CRS.

Salas et al. reported that addition of a total dose of $4.5 \mathrm{mg} / \mathrm{kg}$ ATG prior to stem cell infusion seemed to ameliorate the risk of severe CRS, but this strategy was associated with graft failure for $15.6 \%$ of patients [22]. Ongoing studies will evaluate the effect a single dose of ATG in combination with posttransplant cyclophosphamide on the risk of CRS and graft failure [23].

\section{Pathophysiology and Biomarkers}

3.1. The Development of CRS Involves Various Cells and a Wide Range of Both Immunoregulatory and Angioregulatory Cytokines

Our current understanding of the CRS pathophysiology is incomplete and mainly based on patient serum cytokine profiles, autopsy studies, and animal models. Although the underlying mechanisms of CRS are complex and possibly differ between causes/patients, the final biological effects and clinical manifestations are similar. The most important organ involvements are reduced renal function, pulmonary edema, cardiac dysfunction with reduced cardiac output, activation of platelets and the coagulation factor cascade with secondary disseminated intravascular coagulopathy (DIC), and central nervous dysfunction with seizures and altered mental state [1-4,6,24].

A hallmark of CRS is endothelial dysfunction [6], activation of immunocompetent cells, including macrophages and natural killer (NK)-cells [24]. The main pathophysiological mechanisms in CRS due to CAR-T cell therapy are summarized in Figure $1[1-4,6,24-27]$. The initial event is supraphysiological activation of endogenous and/or infused T cells due to activating interactions with antigen-presenting cells, tumor cells or direct stimulation of $\mathrm{T}$ cells by the antigen-binding fragment (FAB) segment of an antibody. Such interactions result in a massive release of interferon- $\gamma$ (IFN- $\gamma$ ) by the activated T cells. This is followed by the release of a large variety of other cytokines, the most important are IL-6, tumor necrosis factor- $\alpha$ (TNF- $\alpha)$, IL-10, granulocyte-macrophage colony-stimulating factor (GMCSF) and CCL2. These mediators are released by bystander normal immunocompetent cells, such as macrophages, NK-cells, and endothelial cells. However, the mediator can also be released by activated $\mathrm{T}$ cells; and has also been demonstrated for circulating $\mathrm{T}$ cells derived early after allo-HSCT. Hence a broad cytokine response may thus be initiated even during the initial alloreactive response after allo-HSCT [28-30]. 


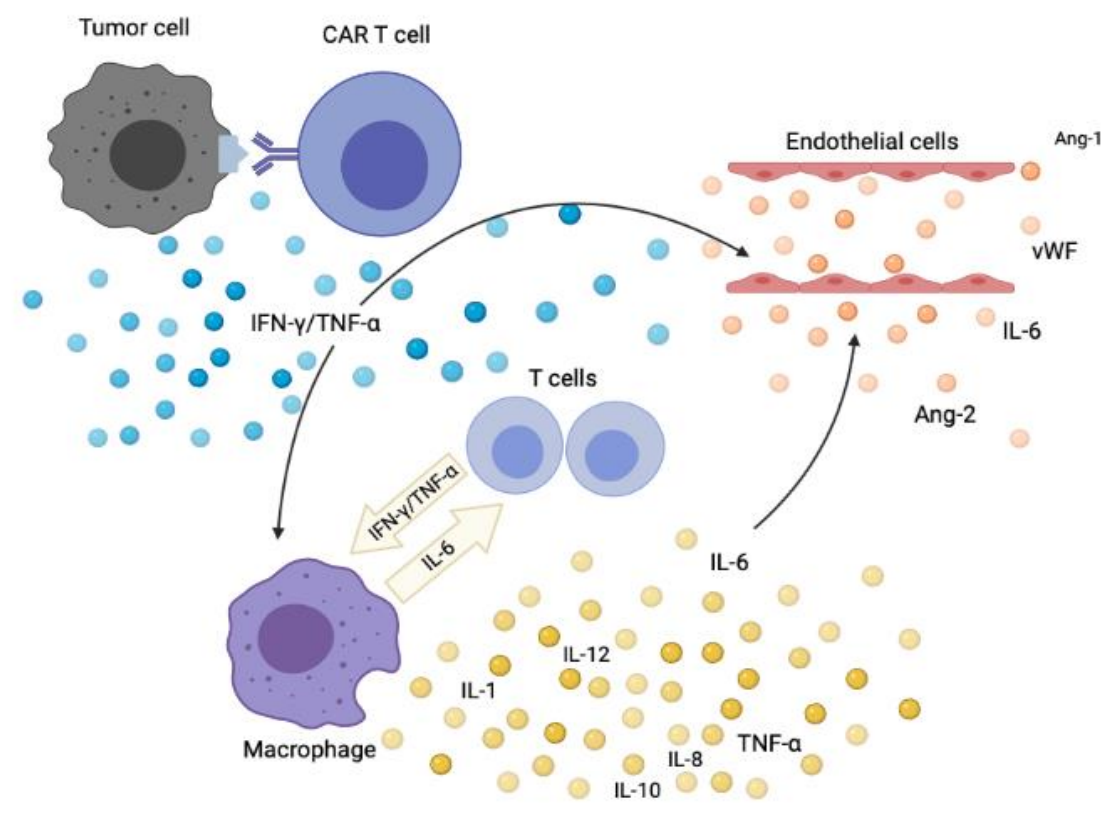

Figure 1. The development of CRS after CAR-T cell therapy. The triggering mechanisms are incompletely understood, but CRS is triggered by the release of immunostimulatory cytokines (e.g., IFN- $\gamma$, TNF- $\alpha$ ) both from the tumor cells and CAR-T cells. Immunocompetent cells as well as stromal cells (e.g., endothelial cells) are subsequently activated and thereby release excessive amounts of proinflammatory cytokines as the final part of a positive feedback loop.

Macrophages care central in the development of CRS [31], and upon activation, macrophages release a wide range of cytokines including both interleukins, chemokines, and immunoregulatory mediators (Figure 1). Many of these are potent modulators of endothelial cell functions and cell migration. CRS shares clinical and biochemical characteristics with several syndromes associated with macrophage dysfunction, such as. hemophagocytic lymphohistiocytosis (HLH) and macrophages activation syndrome (MAS). Several animal models have demonstrated the importance of monocytes/macrophage activation, and that blockade of cytokines from macrophage, i.e., Il- 6 and IL- $1 \beta$, ameliorates CRS $[25,27,32]$. Several of the clinical hallmarks of CRS are believed to be directly linked to macrophages activation: (i) hyperferritinemia due to release of apoferritin from macrophages, (ii) hypofibrinogenemia by release of plasminogen activator inhibitor, (iii) fever due to the release of IL-6, IL- $\beta$, and TNF $\alpha$, and (iv) cytopenias due to the extensive release of interferon- $\gamma[25,27,32]$.

Toll-like receptors (TLRs) and the nuclear factor kappa-light-chain-enhancer of activated B cells (NF- $\mathrm{kB}$ ) pathway are potent activator of monocytes/macrophages [33]. In addition, previous studies have shown that TLRs activation is involved in the development of cytokine storm as a complication to various diseases [34-36]. To the best of our knowledge the possible importance of TLRs, as well as other pattern-recognizing receptors, in the pathogenesis of CRS has not been studied in detail. However, several of these receptors can bind agonistic intrinsic ligands and may thus be ligated by molecules derived from cells that are damaged by or during immunotherapy $[37,38]$. Finally, TLRs have NF- $\kappa B$ as a downstream target, and NF- $\mathrm{KB}$ inhibition (e.g., by direct inhibitors or proteasome inhibitors [39]), should therefore be considered as a possible therapeutic strategy in CRS.

Monocytes include various functionally different subsets [31]; the peripheral blood levels of these subsets differ between allotransplant recipients and normal individuals and these subsets also differ in their kinetics of posttransplant reconstitution [40]. However, it is not known whether or how the balance between various monocyte subsets influences the risk of developing CRS after various forms of immunotherapy, e.g., intensive conventional therapy, autologous (auto-) or allo-HSCT [41]. 


\subsection{Systemic Signs of Inflammation in CRS; Characterization of the Systemic Cytokine Responses} and the Use of Soluble Mediators for Pretreatment Risk Evaluation

Systemic levels of cytokines and other soluble mediators correlates with of severe forms of CRS. As mention previously, clinical factors are important for this evaluation; two previous studies identified the following independent pretreatment risk factors for posttreatment development of severe CRS: high bone marrow tumor burden, concurrent infectious disease, lymphodepletion using cyclophosphamide and fludarabine, higher CAR-T cell dose, thrombocytopenia before lymphodepletion, and preparation of CAR-T cells without selection of $\mathrm{CD}^{+}$central memory T cells $[3,6]$.

The study by Teachey et al. [24] showed that CRS is associated with an extensive cytokine release, including interleukins, chemokines, growth factors and immunoregulatory as well as angioregulatory cytokines (Table 1). As would be expected, the effects of CRS on the systemic mediator levels are most extensive for patients with the most advanced disease. Many of these cytokines can induce an acute phase reaction; e.g., IL-1, IL-6 and TNF- $\alpha$, but other members of the IL- 6 cytokine family can also induce this reaction [42]. Increased levels of acute phase proteins are therefore observed in CRS (Table 2). Increased levels of both C-reactive protein (CRP) and ferritin are seen during CRS, and the increase in ferritin levels can be as high as the levels seen in HLH [24,43-45]. In contrast, fibrinogen is also an acute phase protein, but in the CRS the systemic fibrinogen, it is usually low due to extensive release of plasminogen activator inhibitor from macrophages.

Table 1. The systemic cytokine profile cytokine in patients with cytokine release syndrome; a summary of serum/plasma levels for soluble mediators, soluble receptors and soluble adhesion molecules [6,24,46-50]. If a mediator is listed in both groups, this means that the results are conflicting (see comment in the text). Levels are generally increased; decreased levels are stated in the table. Most studies define advanced disease as Stage 4/5 (see Table 6 and further discussion in Section 4.3).

\begin{tabular}{|c|c|}
\hline Increased in Advanced CRS & No Difference between Low and Advanced Stage CRS \\
\hline \multicolumn{2}{|l|}{ Interleukins } \\
\hline IL1-RA, IL-4, IL-5, IL-6, IL-8, IL-10 & IL-1 $\beta$, IL-2, IL-5, IL-6, IL-7, IL-12, IL-13, IL-15, IL-17, IL-4R \\
\hline sgp130, sIL-1R1, sIL-1R2, IL2-RA, sIL-6R & \\
\hline Chemokines & \\
\hline CCL2, CCL3, CCL4 & \multirow{5}{*}{ CCL5, CCL24 } \\
\hline CXCL9, CXCL10, CX3CL1 & \\
\hline Immunoregulatory mediators & \\
\hline IFN- $\alpha$, IFN- $\gamma$, TNF- $\alpha$ & \\
\hline Growth factors & \\
\hline G-CSF, GM-CSF, Flt3-ligand & \multirow[t]{2}{*}{ EGF, HGF, EGFR, VEGFR1, VEGFR2, VEGFR3 } \\
\hline Angioregulatory mediators & \\
\hline $\begin{array}{l}\text { VEGF, Ang-2, von Willebrand factor } \\
\text { Decreased Ang-1 levels. }\end{array}$ & $\begin{array}{l}\text { Observed differences are not caused by increased frequency of neurotoxicity } \\
\text { because no association with neurotoxicity and serum levels of VEGF-A, Ang-1, } \\
\text { Ang-2 could be detected. }\end{array}$ \\
\hline \multicolumn{2}{|r|}{$e_{0}$} \\
\hline & sCD90 \\
\hline RAGE, Granzyme B & $\begin{array}{c}\text { No association with neurotoxicity and serum levels of International } \\
\text { normalized ratio, D-dimer, vWF, nadir fibrinogen levels. }\end{array}$ \\
\hline
\end{tabular}

Abbreviations: Ang, angiopoietin; EGF, epithelial growth factor; G-CSF, granulocyte colony-stimulating factor; GM-CSF, granulocytemacrophage colony-stimulating factor; HGF, hepatocyte growth factor; IFN, interferon; IL, interleukin; R, receptor; s, soluble; RAGE, receptor for advanced glycation end products; VEGF, vascular endothelial growth factor; vWF, von Willebrand factor.

The overall results presented in Table 1 shows that CRS is characterized by a broad systemic cytokine response with increased levels of a wide range of functionally diverse cytokines. This is true especially for patients with advanced CRS that is usually defined as Stage $4 / 5$ disease (Table 6, and further discussion in Section 4.3), and this staging is also referred to in Table 6. It should be emphasized that even for several cytokines showing highly significant differences there may be a considerable overlap between these two patient subsets, and the cytokine showing the highest fold-increase can differ between patients [46]. One can also see from the table that some cytokines are listed in both columns. First, the 
IL-6 levels are usually substantially increased, but even for this cytokine there is an overlap between patients with advances and less severe CRS and exceptional patients with only a relatively small increase/difference in IL-6 levels have been described $[5,24,48,51]$. For these exceptional patients IL-6 targeting therapy may not be the optimal treatment. Second, IL-5 levels have been investigated only in a few studies, and one of these studies described an increase in IL5 levels for patients with advanced disease that reached borderline significance $(p=0.017)$ and showed a large overlap between patients with advanced and less severe CRS [24] Third, as indicated in Table 1 the levels of Ang-1, Ang-2 and vascular endothelial growth factor (VEGF) are altered in patients advanced CRS; these effects alterations are not caused by a difference in the frequency of neurotoxicity because the levels of these mediators did not differ between patients with and without neurotoxicity [47] Finally, the heterogeneity of CRS patients with regard to cytokine levels can at least partly be explained by differences in tumor burden, i.e., higher levels in patients with large burden) [48], although the median age and/or the frequency of adult patients (and probably/possibly also the pre-CAR T cell chemotherapy) in the various studies differs $[6,24,46,47]$.

Table 2. Systemic signs of inflammation in patients with cytokine release syndrome; systemic levels of selected acute phase proteins and cytokines.

\begin{tabular}{|c|c|c|}
\hline Mediator & Systemic Level in CRS & Refs \\
\hline CRP & $\begin{array}{l}\text { High levels correlate with CRS severity (i.e., staging, see below). A rise is seen } \\
\text { in most patients after CAR-T infusion compared with baseline levels. High } \\
\text { initial levels cannot be used to predict the development of severe CRS. The } \\
\text { initial increase/level cannot predict the clinical course (i.e., the stay at intensive } \\
\text { care unit) in patients with severe disease. One study showed that high early } \\
\text { levels could predict later severe disease; this has not observed in other studies. }\end{array}$ & {$[24,43,44,46,52]$} \\
\hline Ferritin & $\begin{array}{l}\text { A rise is seen in most patients after CAR-T infusion compared with baseline } \\
\text { levels. Increased levels in CRS, the levels correlate with severity/staging and } \\
\text { levels exceeding 10,000 mg/100 mL can be seen both in adults and children } \\
\text { even in Stages 0-3 (for staging, see below). The level at transfer to intensive } \\
\text { care unit has only a weak association with the length of the stay at the unit. }\end{array}$ & {$[24,43,44]$} \\
\hline Fibrinogen & $\begin{array}{c}\text { Although an acute phase protein, fibrinogen levels are either low (especially in } \\
\text { children with severe disease) or normal due to release of plasminogen } \\
\text { activator inhibitor from macrophages. }\end{array}$ & [24] \\
\hline
\end{tabular}

Endothelial cell damage and capillary leak are clinical hallmarks of CRS (Figure 1). The endothelial activation and stress index (EASIX) is defined as [(creatinine level $x$ lactate dehydrogenase (LDH)) level/peripheral blood platelet count], and this marker of endothelial activation has been validated in the CAR-T cell therapy setting [53]. This study included patients who received treatment with CAR-T cells, and the authors investigated the association between EASIX and the immune effector cell-associated neurotoxicity syndrome (ICANS) in a group of 171 patients treated with axicabtagene ciloleucel (axi-cel) for large B-cell lymphoma. Patients were tested before lymphodepletion. CRS Grades 2 to 4 were diagnosed in 81 patients (47\%) and ICANS Grades 2 to 4 in 84 patients $(49 \%)$. Three risk groups for neurotoxicity could be identified when EASIX was combined with ferritin. EASIX was also combined with both CRP and ferritin and again three risk groups for Grades 2 to 4 toxicity could be identified. Thus, common laboratory parameters including endothelial markers and acute phase proteins correlate with CAR-T cells related toxicities.

A wide range of various cytokines, including chemokines, are important for regulation of vascular functions and the endothelial cell status [54]. The systemic levels of such mediators in CRS have been investigated only for some of them, and these observations further support the hypothesis that endothelial and vascular modulation is important in the pathogenesis of CRS [24]. Angiopoietin(Ang)-2 and von Willebrand factor (vWF) are both regarded as markers of endothelial activation, and systemic levels of both these markers are increased in patients with severe CRS both before lymphodepletion (i.e., signs 
of endothelial activation before the treatment) and during the development of CRS [6] (Figure 1).

Neurological involvement in CRS is associated with abnormalities in the cerebrospinal fluid including increased levels of white blood cells, protein, IFN- $\gamma$, IL-6, IL-10, and granzyme B [47]. Furthermore, the cerebrospinal fluid level of the glial fibrillary acid protein is regarded as a marker of astroglial injury whereas the s100 calcium binding protein level indicates astrocyte activation; the spinal fluid levels of both these markers are increased during in CRS with neurotoxicity.

\subsection{The Central Role of IL-6 and Angiopoietins in CRS}

Increased serum IL-6 levels are a hallmark of CRS, and IL-6 blockade effectively ameliorates most symptoms of CRS [24,55-60]. IL-6 exhibits a wide variety of biological effects through classical and IL-6 trans-signaling. Only a limited number of cell types, e.g., naive T cells, hepatocytes, monocytes and neutrophils, express the IL-6 binding IL-6 receptor (IL-6R) chain. The IL-6R is then expressed together with the signal-transducing gp130 transmembrane glycoprotein and these cells can thereby respond to IL-6 alone; this is referred to as classic IL-6 signaling. All other cell types do not express membrane-bound IL$6 \mathrm{R}$ and for this reason IL-6 alone cannot initiate intracellular signaling. However, most cells express the gp130 signal-transducing glycoprotein, and these cells can bind and thereby respond to the soluble complex of IL-6 and IL6R. This IL-6/IL-6R initiation of intracellular gp130-mediated intracellular signaling is referred to as IL-6 trans-signaling. This transsignaling is thus regulated by the release of soluble IL-6R. Trans-signaling is believed to contribute to the development of many CRS symptoms and signs, i.e., disseminated intravascular coagulation, vascular leakage and myocardial dysfunction [57-59]. The peak systemic levels of IL-6, soluble IL-6 receptor, IFN- $\gamma$, and soluble gp130 directly correlate with the risk of developing severe CRS [24].

A recent study demonstrated that severe CRS coincided with elevated serum levels of vWF and Ang-2, both released from Weibel-Palade bodies on endothelial activation [6]. Furthermore, high serum vWF level and Ang-2: Ang-1 ratio were observed prior to CAR $\mathrm{T}$ cell therapy for patients who developed more severe CRS. Lastly, severe CRS was also associated with thrombocytopenia before lymphodepleting chemotherapy, possibly due to the lack of the endothelial stabilizing cytokine Ang-1, of which thrombocytes are a main source [6]. Taken together, these findings suggest that preexisting and excessive endothelial activation might be risk factors for severe CRS.

\subsection{Potential Biomarkers in CRS}

As described above CRS is associated with altered systemic levels of a wide range of soluble mediators (Tables 1 and 2). Non-specific markers of inflammation such as CRP and ferritin are obligate elevated in CRS and correlate with the disease severity. However, they fail at predicting the occurrence of severe CRS [24,47]. Teachey et al. identified a series of cytokines significantly elevated in CRS that that correlated with the occurrence of severe CRS. By evaluating the concentrations of IFN- $\gamma$, IL-13, and CCL3 in pediatric patients, this model achieved a sensitivity of $100 \%$ and specificity of $96 \%$. This was subsequently validated in an independent cohort of 12 pediatric patients [24]. However, their predicting models evaluate the cytokines within $72 \mathrm{~h}$ after infusion, which may diminish its clinical value as severe CRS frequently occurs earlier and often within $72 \mathrm{~h}$ after infusion $[2,6,61]$. A timelier method was reported by Hay et al.; evaluation of CCL2, measured in patients with temperature $>38.9^{\circ} \mathrm{C}$ and within $36 \mathrm{~h}$ of infusion, was found to be superior to CRP, ferritin, and other cytokines in predicting severity CRS [6]. Simple predictive models using the combination of clinical parameters and biomarkers may be more suited for routine clinical practice, as testing for the aforementioned cytokines are not commonly available. Further studies are needed to validate and develop viable predictive models.

As stated above the EASIX index has also been investigated as a possible biomarker in combination with CRP and ferritin [53]. This index could identify three different patient 
subsets regarding development of CRS Grades 2-4 with 74\%, 51\%, and 29\% cumulative incidences. This index should also be suitable for routine clinical practice, although it can be questioned whether the combination with CRP/ferritin is helpful because the classification into three groups and the corresponding cumulative indices are very similar to the results when using the original index alone.

In our opinion, there are several possible additional mediators that should be further investigated as possible biomarker in CRS. Especially, specific metabolites previously been shown to correlate endothelial cell dysfunction, capillary leak and or altered renal functions, and factor of complement system due to the crucial role of various complement fragment to initial cell migration and vascular leakage.

First, several metabolites are associated with capillary leak and or altered renal functions and due to the importance of endothelial cell dysfunctions in CRS these markers should also be investigated in CRS [62]. Second, there is activation of the complement system $[63,64]$. Finally, more detailed investigations of immunocompetent cell subsets should be investigated, especially monocyte subset distribution and monocyte activation that is important in endothelial/vascular biology $[65,66]$.

The possible use of soluble adhesion molecules as biomarker in CRS should also be further investigated [67-70]. The systemic levels of several adhesion molecules derived from both immunocompetent and endothelial cells can be released during inflammation, these molecules show biological activity, they can have immunoregulatory functions and may also be involved in regulation of coagulation. Their possible role as biomarkers in CRS should be further investigated, e.g., biomarkers for endothelial activation.

\subsection{The Biological Heterogeneity of CRS Patients}

Patients with CRS seem to be heterogeneous with regard to certain cytokines, although this heterogeneity seems to be limited. First, most studies describe increased IL-6 levels, but some exceptional patients / studies do not show increased systemic IL-6 levels [24,48]. Second, both increased and unaltered levels have been described for IL-5 [24,47], the same is true for detection of coagulopathy $[6,48]$. Finally, the predictive value of early CRP levels (i.e., first three days after CAR-T cell infusion) has not been seen in all studies either [24,47]. This possible heterogeneity between patients' needs to be further investigated, especially emphasizing the possible relevance for diagnosis and the choice of cytokine-targeting treatment.

Development of an acute phase reaction seems to be a common characteristic in CRS, but this reaction can be initiated by various cytokines including IL-1, TNF- $\alpha$, and IL- 6 as well as other members of the IL-6 family [43]. Although certain cytokines seem to be more important than others and therapeutic targeting of single cytokines is often effective, in our opinion, it is most likely that the acute phase reactions reflect the contribution of several cytokines to CRS development. For this reason, one should also investigate the possible diagnostic value of extended cytokine profiles in addition to single cytokine levels in future clinical studies. This diagnostic approach would be similar to the approach used in recent studies of human cancer; CRP has a prognostic impact both in renal cancer and head and neck squamous cell carcinoma, but the acute phase cytokine profile differs between them [71,72]. Thus, the molecular mechanisms behind the acute phase reaction differ between these two cancers, and a similar heterogeneity may also exist for CRS patients.

\subsection{The Lessons from Studies of Animal Models}

Two animal models of CRS following CAR-T cell therapy have recently been published [25,27]; the main characteristics of these models and the most important observations are summarized in Table 3. First, the importance of host macrophages in the development of CRS was demonstrated in both studies. Second, therapeutic targeting of both IL-1 and IL-6 could be effective, but the two therapeutic strategies differed regarding their clinical effects. This targeting did not influence the antileukemic effects. Finally, other therapeutic targets were also suggested, including CD40-initiated signaling and targeting of nitric 
oxide synthase. Thus, both these models seem relevant for future studies of potential new biomarkers (e.g., soluble adhesion molecules, metabolites, extended cytokine profiles) and new therapeutic strategies/targets.

Table 3. Animal models for CRS; description of two various models and the most important observations [25,27].

\begin{tabular}{c} 
Giavridis et al. [25] \\
\hline Design of the \\
Immunocompromised mice \\
Intraperitoneal injection of Burkitt lymphoma Rajiv cells and \\
NALM-6 pre-B ALL cells; mice were tested when vascularized \\
tumors had developed intraperitoneally. \\
CD18 recognizing CAR-T cells (human 1928 CAR-T cells)
\end{tabular}

CAR-T cell recognition of the malignant cells Tumor infiltration of myeloid cells

\section{Systemic inflammatory markers}

The systemic cytokine profile was very similar to patient CRS, including increased levels of the murine CRP equivalent; G-CSF, GM-CSF, IFN- $\gamma$, IL-2, IL-3, and IL-6

\section{The role of monocytes}

The mice developed a broad cytokine response, including increased levels of a murine CRP analogue as well as IL1, IL-6, IL-10, and TNF- $\alpha$.

Norelli et al. [27]

Immunocompromised mice

Human cord blood hematopoietic stem and progenitor cells were injected into the liver to reconstitute human hematopoiesis and development of immunocompetent cells. $\mathrm{T}$ cells from the mice were reconstituted with anti-CD44w6 or CD1920z CARs.

THP1 and BV173 cells were used, in addition they used an ALL-CML cell line derived from a patient with CML in lymphoid blast phase and transfected with CD44 isoforms. These malignant cells were infused intravenously.

CAR-T cells had antileukemic effects; recognized the specific CD44 isoform and had a durable antileukemic effect.

Host monocytes were a main source of released cytokines Monocytes express CD40 receptors, expression of CD40 ligand by CAR-T cells increased the severity of CRS

CD40 ligation also increased the cytokine release by host monocytes. Expression of nitric oxide synthase was increased; aberrant nitric oxide production seemed to be directly involved in CRS pathophysiology probably due to its endothelial and/or vascular effects.

\section{Effects of therapeutic interventions}

Monocytes were a major source of both IL-1 and IL-6. The monocytes expressed high levels of IL- 1 , IL- 6 , IL-8/CXCL8, CCL2, CCL8, and CXCL10.

Dendritic cells also contributed to cytokine production.

Effects of therapeutic interventions
IL-1RA/akinera protected from lethal neurotoxicity, this
was a unique effect. $\begin{gathered}\text { Tocilizumab also reduced CRS mortality. } \\ \text { CRS treatment did not influence the antileukemic effect of } \\ \text { CAR-T cells. }\end{gathered}$

\section{Clinical Evaluation of Patients with Suspected CRS: Symptoms and Signs, Diagnostic Work up, Differential Diagnoses, and Grading \\ 4.1. Clinical Manifestations}

The onset and peak of CRS generally occurring in the first week after therapy. Clinical manifestations of CRS vary (Table 4) from mild, flu-like symptoms to severe life-threatening multiorgan failure secondary to an uncontrolled inflammatory response. High fever is seen for most patients, although not all [73,74]. Mild symptoms of CRS include fatigue, rash, arthralgia, and myalgia, whereas more severe cases are characterized by vasodilatation with subsequent hypotension; this can develop into an uncontrolled systemic inflammatory response with vasopressor-demanding vasodilatory shock and severe vascular leakage $[73,74]$. Furthermore, a cytokine induced cardiac dysfunction is sometime observed as a rapidly progressing cardiomyopathy with clinical features of stress cardiomyopathy (i.e., Takotsubo syndrome) [75]. Cardiac dysfunction, neurologic toxicity, renal failure, hepatic failure and DIC, can all be seen in fulminant CRS [73,74]. CRS is usually reversible. 
Table 4. Major symptoms of CRS after organ involvement.

\begin{tabular}{cc}
\hline Organ System & Symptoms \\
\hline Constitutional & Fkin \\
Gastrointestinal & Fever \pm general malaise, fatigue \\
Muscle, skeletal & Rash \\
Respiratory & Nausea, vomiting, diarrhea, anorexia \\
Cardiovascular & Myalgia, arthralgia \\
Coagulation & Tachypnea, hypoxemia \\
Renal & Tachycardia, dilated pulse pressure, hypotension, heart failure \\
Liver & Elevated D-dimer, hypofibrinogenemia, bleeding \\
Neuremia
\end{tabular}

Central nervous system (CNS) symptoms are sometimes seen in conjunction with CRS. However, due to a possible different pathophysiological mechanism neurologic toxicity that is observed after immunotherapy, is termed either immune effector cell-associated neurotoxicity syndrome (ICANS) or cytokine release encephalopathy syndrome (CRES). Symptoms range from headache, memory difficulties, diminished attention, and language disturbance to confusion, delirium, aphasia, motor weakness, myoclonus, seizure and signs of cerebral edema [73]. Although most cases of neurological toxicity are reversible, life-threatening cerebral edema in patients with CRS has been reported. Other symptoms may also occur and are classified in the table below according to the affected organ system (Table 4).

\subsection{Diagnostic and Differential Diagnoses}

There are currently no single diagnostic tests that can differentiate CRS from sepsis, allergic reactions or HLH. Common laboratory abnormalities in patients with CRS include cytopenia, elevated creatinine and liver enzymes, disturbed coagulation parameters, and high CRP levels. As described above CRS is usually associated with high levels of interferon- $\gamma$ IL-6, TNF- $\alpha$ and IL-10 [6]. However, currently there are no clear correlation between cytokine levels, disease severity and outcome. High ferritin levels indicate macrophage activation or a HLH similar to clinical picture. Currently, CRS, remains an exclusion diagnosis and several differential diagnoses have to be excluded (Table 5). Infections have to be excluded by adequate microbiological examination including blood and urine cultures together with sampling from relevant organs systems [76]. Evaluation of left ventricular function by echocardiography is required in patients with sign of cardiac dysfunction [75]. Radiological examinations preferably computed tomographic (CT) with intravenous contrast, and bronchial lavage are required to adequate rule out other cause of acute respiratory distress syndrome (ARDS).

CRS may also be associated with signs consistent with MAS or HLH [77]. MAS/HLH is a hyperinflammatory syndrome that shares features and is probably related to CRS. Both CRS and HLH include signs of macrophage activation and cytokine storm [77]. Examination of ferritin, triglycerides, fibrinogen and soluble interleukin-2 receptor (soluble CD25) can provide diagnostic information regarding HLH [77]. However, most patients with moderate to severe CRS have laboratory results that meet the classical criteria for HLH/MAS, although hepatosplenomegaly, lymphadenopathy, and overt evidence of hemophagocytosis are less common. Both CRS and HLH show increased levels of IFN- $\gamma$ together with $\mathrm{T}$ cell activation, but the main cause of T cell activation in HLH is believed to be insufficient regulation of $\mathrm{T}$ cells by absent/reduced NK-cell function. Furthermore, a well-defined genetic predisposition can trigger the cytokine storm in HLH, but the secondary forms of HLH are less well defined and especially for haplotransplant recipients a clear distinction between CRS and HLH is not always possible. 
Table 5. Main differential diagnosis and clinical characteristics for CRS.

Differential Diagnosis Clinical Characteristics

Sepsis

\section{Disease progression}

Tumor lysis syndrome

Heart failure

Venous thromboembolism

Acute respiratory distress syndrome (ARDS)

Allergic reaction/anaphylactic reaction

Hemophagocytic lymphohistiocytosis (HLH)
Sepsis can cause fever, hypotension, and respiratory complications. The evaluation for infection should include adequate microbiological diagnostics including blood cultures. It will often be necessary to initiate empirical antibiotic therapy.

Rapid progression of underlying malignancy can cause fever and a clinical, metabolic image similar to CRS.

The direct decay of malignant cells, especially in lymphoid malignancies, can cause metabolic disorders, with laboratory and clinical findings similar to CRS.

Cardiac failure due to cardiomyopathy, ischemic heart disease or pericardial effusion, may produce a clinical picture with respiratory failure as in severe CRS.

Clinical features of pulmonary embolism (PE) and deep vein thrombosis

(DVT) such as dyspnea, hypoxia, hypotension, peripheral edema and swelling in the extremities may resemble CRS. Image diagnostics for this purpose may be relevant for diagnostic clarification.

Respiratory problem is the dominant symptom, with fluid accumulation in the lung tissue that can produce characteristic radiological changes.

Allergic reactions including severe drug reactions can cause fever, rash, capillary leakage and dyspnea. An overview of recent changes in the drug regimen should therefore be reviewed in case of suspected CRS.

HLH is a hyperinflammatory syndrome that shares common features and is likely related to CRS. Both by CRS and HLH are macrophage activation and cytokine storm.

Tumor lysis syndrome (TLS) may occur coincidently together with CRS because of massive immune cell activation/expansion and a strong anticancer effect. The patients should therefore be evaluated for the typical disturbance associated with TLS; i.e., hyperuricemia, hyperpotassemia, hyperphosphatemia and hypocalcemia [64]. Furthermore, tumor/leukemia progression, in the setting of relapse or refractory disease, can also occur and should be kept in mind by uncharacteristic and progressive symptoms. Finally, allergic reactions, especially severe drug reactions, can cause symptoms resembling CRS with fever and hypotension, and work up regarding the patient's recent medications should be performed.

\subsection{Grading of CRS}

Several grading systems for CRS have been developed; for this reason, the grading systems applied in various studies therefore vary widely, making comparisons between different studies/clinical trials difficult. Furthermore, in an initial definition CRS onset was defined as within $24 \mathrm{~h}$ after initiation of therapy, but later studies have shown that this is not always true and should not be used as a criterion, especially not for CRS associated with CAR-T cells and other cell therapies. In addition, the previous grading as included as a criterion, whether the drug infusion was interrupted, an approach that is less relevant for cellular therapy.

The Lee criteria [73] established in 2014 have been regarded as the most relevant criteria for clinical practice (Table 6). However, a new grading system has recently been proposed by the American Society for Transplantation and Cellular Therapy (ASTCT) with the aim of providing a uniform consensus grading system for CRS (Table 7) [74]. These new criteria are only based on fever, hypotension and hypoxia (Table 7) In this scoring system the CRS grade is determined by the most severe event in CRS, i.e., fever, hypotension or hypoxia that cannot be attributed to any other cause. For example, a patient with a temperature of $39.5^{\circ} \mathrm{C}$, hypotension requiring one vasopressor, and hypoxia requiring low-flow nasal cannula is classified as Grade 3 CRS. This scoring system relies on welldefined clinical data and is relatively easy to interpret. The aim of this scoring system is to 
allow comparison across different sites and clinical trials, and thereby to facilitate optimal strategies for prevention and management of CRS. Finally, because immune effector cellassociated CRS can be associated with high morbidity and mortality rates if not recognized and treated properly, the new CRS grading was developed to accurately captures these early features of the condition [74]. A staging system only based on clinical parameters can also be used for all patients independent of the possible patient heterogeneity with regard to the pathogenesis, proinflammatory signaling and differences in organ involvement.

Table 6. Classification of CRS severity according to the Lee criteria [73].

GRADE SYMPTOMS

\section{GRADE 1}

GRADE 2

GRADE 3

\section{GRADE 4}

GRADE 5

Fever $\geq 38.0^{\circ} \mathrm{C}$. Symptoms are not life-threatening and require only symptomatic treatment (e.g., fever, nausea, headache, muscle pain, fatigue)

Fever $\geq 38{ }^{\circ} \mathrm{C}$. Symptoms need and respond to moderate measures: (i) oxygen requirements $<40 \%$ ( $\leq 6 \mathrm{~L} /$ minute), (ii) hypotension responding to IV fluid or low dose vasopressor1, or (iii) Grade 2 organ toxicity

Fever $\geq 38{ }^{\circ} \mathrm{C}$. Symptoms need and respond to aggressive measures: (i) oxygen demand $\geq 40 \%$ ( $\geq 6 \mathrm{~L} /$ minute), (ii) hypotension requiring high dose or multiple vasopressors ${ }^{1}$, (iii) Grade 3 organ toxicity ${ }^{2}$, or (iv) Grade 4 transaminitis ${ }^{3}$

Fever $\geq 38^{\circ} \mathrm{C}$. Life-threatening symptoms In need of CPAP, BiPAP or ventilator support, or Grade 4 organ toxicity ${ }^{2}$ Mors

${ }^{1}$ High dose vasopressors: noradrenaline $\geq 20 \mathrm{mcg} / \mathrm{min}$, dopamine $\geq 10 \mathrm{mcg} / \mathrm{kg} / \mathrm{min}$, adrenaline $\geq 10 \mathrm{mcg} / \mathrm{min}$, phenylephrine $\geq 200 \mathrm{mcg} / \mathrm{min} .{ }^{2}$ Organ toxicity as defined by the Common Terminology Criteria for Adverse Events (CTCAE) v5.0. ${ }^{3}$ Transaminitis as defined by CTCAE v5.0. Abbreviations: BiPAP, bilevel positive airway pressure; CPAP, continuous positive airway pressure.

Table 7. Classification of CRS severity according to the ASTCT criteria [74].

\begin{tabular}{|c|c|c|c|c|}
\hline CRS Parameter & Grade 1 & Grade 2 & Grade 3 & Grade 4 \\
\hline \multicolumn{5}{|c|}{$\operatorname{cosec}=50$} \\
\hline Hypotension & None & Not requiring vasopressors & $\begin{array}{l}\text { Requiring a vasopressor with } \\
\text { or without vasopressin }\end{array}$ & $\begin{array}{c}\text { Requiring multiple } \\
\text { vasopressors } \\
\text { (excluding vasopressin) }\end{array}$ \\
\hline \multicolumn{5}{|c|}{ AND/OR } \\
\hline Hypoxia & None & $\begin{array}{l}\text { Requiring low-flow nasal } \\
\text { cannula }{ }^{1} \text { or blow-by }\end{array}$ & $\begin{array}{c}\text { Requiring high-flow nasal } \\
\text { cannula } 1 \text {, facemask, } \\
\text { nonrebreather mask, or } \\
\text { Venturi mask }\end{array}$ & $\begin{array}{c}\text { Requiring positive pressure } \\
\text { (e.g., CPAP, BiPAP, } \\
\text { intubation or mechanical } \\
\text { ventilation) }\end{array}$ \\
\hline
\end{tabular}

${ }^{1}$ Low-flow nasal cannula is defined as oxygen delivered at $\leq 6 \mathrm{~L} / \mathrm{min}$. Low flow also includes blow-by oxygen delivery, sometimes used in pediatrics. High-flow nasal cannula is defined as oxygen delivered at $>6 \mathrm{~L} / \mathrm{min}$. Abbreviations: BiPAP, bilevel positive airway pressure; $\mathrm{CPAP}$, continuous positive airway pressure.

\subsection{Heterogeneity of CRS Patients; the Clinical Evidence}

CRS is a heterogeneous disease. First, as described in Section 3.5 there is biological evidence for CRS heterogeneity, e.g., descriptions of exceptional patients with regard to the systemic cytokine profiles, even patients with normal IL-6 levels. Second, CRS can be caused by very different immunotherapies (e.g., CAR-T cells, allo-HSCT). One would also expect that differences in previous anticancer chemotherapy (type, intensity and duration of chemotherapy) would influence the pretreatment immunological status of these patients and thereby modulate the pathogenesis of CRS [78]. Third, one would in addition expect age-dependent differences in the immune system to influence the risk and/or development of CRS [79]. Finally, development of CRS is associated with many different risk factors (including several clinical risk factors), and it would not be surprising if these very different biological and clinical factors mediated their effects through different molecular mechanisms. 


\section{Treatment}

\subsection{General Suggestions}

The treatment of CRS in allo-HSCT recipients has been investigated in very few clinical studies. This is in contrast to CAR-T and BiTE studies, where the treatment is usually based on the grading of the syndrome (see Section 3.4) and on the general experience from patients with other causes of CRS.

Patients with Grade 1 CRS (Table 6) are regarded to have symptoms that are not life threatening, and hence supportive and symptomatic therapy should be the main focus for this patient group [73]. This can include treatment for fever, nausea, and pain (e.g., headache, myalgia). Supportive care is thus needed, but close monitoring, including fluid balance and organ functions, and response evaluation is also important regarding reclassification of the patients based on the response to the initial fluid/vasopressor treatment. A continued evaluation with a focus on development of complicating infections is necessary both for these patients as well as patients with more advanced CRS stages. The endothelial involvement in CRS with extensive capillary leak may limit the response to fluid therapy alone [6]; and previous studies suggest that extensive posttransplant fluid retention/capillary leak in allotransplant recipients is associated with an adverse prognosis [62,80].

Grade 2 (Table 6) has been defined as hypotension that can be handled with fluid or only low-dose treatment with one vasopressor, mild respiratory symptoms responsive to low-flow oxygen, or Grade 2 organ involvement [73]. Patients with Grade 2 should be considered for immunosuppressive treatment, whereas patients with Grade 3 or more should receive immediate treatment [81]. The decision whether to start with immunosuppressive treatment should probably be based on a general clinical evaluation, and immunosuppression should be started early especially for elderly patients and patients with comorbidities who are judged not to be able to tolerate the altered hemodynamics and/or organ involvement associated with the syndrome. Independent of whether immunosuppressive treatment is initiated these patients should receive vigilant supportive care and close monitoring as described above for patients with Grade 1 disease. One should also remember that the potentially life-threatening complications in CRS are cardiac dysfunctions, respiratory distress syndrome, neurological toxicity, severe renal or hematological failure, and severe coagulopathy $[73,74]$. One should also keep in mind that close monitoring is necessary for Grade 2 patients regarding the dose of vasopressors needed for treatment of hypotension; the need for high-dose or multiple vasopressor treatment is a Grade 3 criteria as defined in Table 6 [73].

\subsection{IL-6 Targeting Therapy}

Tocilizumab is regarded as the first-line treatment by several authors [74,82]; this is a monoclonal antibody that binds to both soluble and membrane-bound IL-6 receptors and thereby prevents IL-6 binding to its receptor [82]. IL-6 inhibition is an effective treatment in many patients and response rates up to $70 \%$ in patients with severe CRS [82], the approve treatment for patients above 2 years of age is $8 \mathrm{mg} / \mathrm{kg}$ for adults and $12 \mathrm{mg} / \mathrm{kg}$ for patients with less than $30 \mathrm{~kg}$ body weight; the maximal single dose should be $800 \mathrm{mg}$ and the interval between consecutive doses should be at least $6 \mathrm{~h}$ [82]. Many patients respond to this treatment within few hours or within two days; if no effect is seen within $24-72 \mathrm{~h}$ a second administration is feasible [82]. Other authors recommend a second dose and/or a second immunosuppressive agent already after $24 \mathrm{~h}$ if the patient's condition has not improved or stabilized within $24 \mathrm{~h}$ [73]. Some aspects have to be emphasized with regard to tocilizumab. First, IL-6 is a driver of the CRP response and for this reason CRP is not a reliable biomarker for the severity of the cytokine release syndrome after administration of IL-6 targeting treatment [73]. Second, tocilizumab side effects may overlap with the clinical picture of CRS, e.g., transaminitis, thrombocytopenia (neutropenia seems less common), altered cholesterol/lipoprotein serum levels [73]. Finally, IL-6 levels can show a transient increase following tocilizumab administration [73]. 
Alternative strategies for IL-6 targeting could be siltuximab or clazakizumab; both these monoclonal antibodies bind to IL-6, thereby inhibiting classical and IL-6 transsignaling [82].

\subsection{Corticosteroids and Other Alternative Therapeutic Strategies}

Corticosteroids are also effective in the treatment of CRS. Since corticosteroid inhibits T-cell proliferation and thereby possibly T-cell survival, it was believed that treatment with corticosteroids could hamper the T-cell mediated antitumor effect. Corticosteroids was therefore regarded as a second line therapy [73]. This recommendation/suggestion was however, based on a limited clinical experience with steroids and the fact that tocilizumab is often effective, responses are often rapid, and the general immunosuppressive effects are regarded as less severe with regard to both anticancer immune reactivity and risk of complicating infections [73]. In more recent CAR-T and BiTe studies, steroids are used to a greater extent and earlier in the CRS treatment algorithm with no apparent loss of anti-tumor effect.

It should also be emphasized that the clinical experience in allotransplant recipients is limited, and the clinical experience from patients with other causes of cytokine release syndrome may not necessarily be relevant for the priority between tocilizumab and corticosteroids as the first-line treatment in allotransplant recipients. It may also be relevant to consider combined treatment in patients with severe, life-threatening disease [73]. The dosing and choice of steroid should probably be individualized and adjusted to close monitoring of the patients, but commonly used doses have been methylprednisolone $2 \mathrm{mg} / \mathrm{kg} /$ day that is weaned over several days or dexamethasone $0.5 \mathrm{mg} / \mathrm{kg}$ with a maximal dose of $10 \mathrm{mg} /$ dose $[73,83]$. It may be relevant to prefer dexamethasone in patients with neurological symptoms due to its more efficient penetrance to the central nervous system $[42,47,74]$.

As described more in detail in a recent review the acute phase reaction is initiated and strengthened through the release of several cytokines and not only IL-6; other IL-6 family members as well as IL-1 $\beta$ and TNF- $\alpha$ can contribute to the development of the acute phase reaction and the cytokine release syndrome [82]. The cytokine release syndrome should be regarded as an extreme inflammatory response including an extreme acute phase reaction with the increase of several cytokines including increased systemic levels of IL-6, other IL- 6 family members, IL- $1 \beta$, TNF- $\alpha$ as well as various proinflammatory CCL and CXCL chemokines [82]. This assumption is further supported by the high CRP levels and the clinical picture that may fulfill the criteria for sepsis even in the absence of an infection $[73,74,82]$. Furthermore, clinical studies of CRS patients also suggest that additional cytokines are involved in the development of this complication [24]. Finally, the cytokine release syndrome is regarded as a non-antigen specific toxicity due to high-level immune activation [73]; it involves several immunocompetent or immunoregulatory cell subsets including $\mathrm{T}$ cells, monocytes/macrophages and endothelial cells (see Figure 1) and all these cells can release or respond to a wide range of cytokines when they become activated (e.g., IL- $1 \alpha / \beta$, TNF- $\alpha$, IL-6, other IL-6 family members, CCL and CXCL chemokines) $[28,29,33,84-87]$. For these reasons, other molecular mechanisms in the development of the acute phase reaction/CRS may become relevant in the CRS treatment in allotransplant recipients, including TNF- $\alpha$ neutralizing antibodies (infliximab), soluble TNF- $\alpha$ receptors or IL-1 receptor-based inhibitors (recombinant IL1 receptor antagonist, anakinra) $[73,74]$. Such therapeutic strategies have clinically relevant effects in HLH and MAS [73,74,88]; and this experience may be relevant because CRS may fulfill the criteria even for these two inflammatory diseases at least in certain patients [73,74,82,89]. IL-6 may also promote the development of dysfunctional cytotoxic cells in CRS [90]; this represents an additional functional similarity between cytokine release syndrome and HLH/MAF. 


\section{Prognosis}

The possible prognostic impact of CRS has been investigated only in a few studies. It may have a prognostic impact in allotransplant recipients through its association with later development of graft versus host disease, and the immunosuppressive treatment may also interfere with the antileukemic immune reactivity after allotransplantation.

Previous studies have demonstrated that pretransplant signs of inflammation with increased CRP levels are associated with adverse prognosis in allotransplant recipients [80], and it would not be surprising if development of a severe inflammatory response early posttransplant had a similar effect. This is further supported by a recent study suggesting that there is an adverse prognostic impact of pretransplant as well as early posttransplant IL-6 levels in patients receiving haploidentical allotransplantation [91]. Finally, patients with CRS (mainly low-grade CRS) after haploidentical transplantation seem to have an increased frequency of severe acute GVHD, although these authors could not detect any association between previous CRS and non-relapse mortality or overall survival [81,92].

A recent study described a very high frequency of posttransplant CRS in haploidentical stem cell transplantation, but severe CRS (i.e., Grades 3-5, see Table 6) occurred in 15-20\% of their patients and these patients had a mortality of $24 \%$ [92]. Patients with severe CRS also had increased non-relapse mortality ( 38 vs. $8 \%$ ). Severe CRS was most common in elderly patients and patients with a history of radiation therapy. Shorter median survival for haploidentical allotransplant recipients with severe CRS was also described in another recent study; these last authors also described later neutrophil reconstitution for CRS patients and tocilizumab therapy seemed to be well tolerated [21]. Both these studies were relatively small and the possible prognostic impact of IL-6 targeting therapy on the risk of later relapse could not be investigated.

To conclude, severe CRS after allotransplantation is uncommon, has a high mortality and seems to be associated with increased overall non-relapse mortality. However, additional studies are needed to better clarify the prognostics impact, especially with regard to posttransplant antileukemic activity and relapse risk.

\section{Conclusions}

CRS is a potentially life-threatening complication after various forms of $\mathrm{T}$ cell-based immunotherapy. Even though the clinical context is very different, these patients usually have in common a strong acute phase reaction and increased systemic levels of a wide range of cytokines. Several organs can be affected, and the severity differs between patients. In our opinion future clinical studies have to include more detailed studies of the molecular and cellular mechanisms behind the development of the syndrome. A generally accepted standardization of the patient staging/classification regarding severity is then required. There should in addition be a focus on patient heterogeneity not only with regard to risk of CRS but also with regard to molecular mechanisms and whether the treatment for individual patients should be based on targeting of selected cytokines (e.g., IL-1 and/or IL-6) or a general anti-inflammatory treatment (e.g., steroids). It will also be important to study possible late effects of this syndrome and the quality of life for patients who have developed this complication after anti-cancer therapy [93].

Author Contributions: Conceptualization, H.R; investigation, T.H.A.T., A.K.V., Ø.B. and H.R.; writing-original draft preparation, T.H.A.T., A.K.V., Ø.B. and H.R.; writing-review and editing, T.H.A.T., A.K.V., Ø.B. and H.R.; visualization, A.K.V.; supervision, Ø.B. and H.R.; project administration, H.R.; funding acquisition, H.R. All authors have read and agreed to the published version of the manuscript.

Funding: The research related to allo-HSCT was funded by Helse Vest, The Norwegian Cancer Society, Rakel and Otto Kristian Bruun's fund, Øyvinn Mølbach-Pedersens fund, Family Blix fund, and Norwegian Society of Internal Medicine.

Data Availability Statement: No new data were created or analyzed in this study. Data sharing is not applicable to this article. 
Conflicts of Interest: The authors declare no conflict of interest related to the manuscript. The funders had no role in the design of the study, interpretation of data; in the writing of the manuscript, or in the decision to publish the paper.

\section{References}

1. Chatenoud, L.; Ferran, C.; Reuter, A.; Legendre, C.; Gevaert, Y.; Kreis, H.; Franchimont, P.; Bach, J.F. Systemic reaction to the anti-T-cell monoclonal antibody OKT3 in relation to serum levels of tumor necrosis factor and interferon-gamma [corrected]. $N$. Engl. J. Med. 1989, 320, 1420-1421. [CrossRef] [PubMed]

2. Murthy, H.; Iqbal, M.; Chavez, J.C.; Kharfan-Dabaja, M.A. Cytokine Release Syndrome: Current Perspectives. Immunotargets Ther. 2019, 8, 43-52. [CrossRef] [PubMed]

3. Frey, N.; Porter, D. Cytokine Release Syndrome with Chimeric Antigen Receptor T Cell Therapy. Biol. Blood Marrow Transpl. 2019, 25, e123-e127. [CrossRef] [PubMed]

4. Yu, J.; Wang, W.; Huang, H. Efficacy and safety of bispecific T-cell engager (BiTE) antibody blinatumomab for the treatment of relapsed/refractory acute lymphoblastic leukemia and non-Hodgkin's lymphoma: A systemic review and meta-analysis. Hematology 2019, 24, 199-207. [CrossRef] [PubMed]

5. $\quad$ England, J.T.; Abdulla, A.; Biggs, C.M.; Lee, A.Y.Y.; Hay, K.A.; Hoiland, R.L.; Wellington, C.L.; Sekhon, M.; Jamal, S.; Shojania, K.; et al. Weathering the COVID-19 storm: Lessons from hematologic cytokine syndromes. Blood Rev. 2021, 45, 100707. [CrossRef]

6. Hay, K.A.; Hanafi, L.A.; Li, D.; Gust, J.; Liles, W.C.; Wurfel, M.M.; Lopez, J.A.; Chen, J.; Chung, D.; Harju-Baker, S.; et al. Kinetics and biomarkers of severe cytokine release syndrome after CD19 chimeric antigen receptor-modified T-cell therapy. Blood 2017, 130, 2295-2306. [CrossRef]

7. Rafiq, S.; Hackett, C.S.; Brentjens, R.J. Engineering strategies to overcome the current roadblocks in CAR T cell therapy. Nat. Rev. Clin. Oncol. 2020, 17, 147-167. [CrossRef]

8. Suntharalingam, G.; Perry, M.R.; Ward, S.; Brett, S.J.; Castello-Cortes, A.; Brunner, M.D.; Panoskaltsis, N. Cytokine storm in a phase 1 trial of the anti-CD28 monoclonal antibody TGN1412. N. Engl. J. Med. 2006, 355, 1018-1028. [CrossRef]

9. Haber, L.; Olson, K.; Kelly, M.P.; Crawford, A.; DiLillo, D.J.; Tavare, R.; Ullman, E.; Mao, S.; Canova, L.; Sineshchekova, O.; et al. Generation of T-cell-redirecting bispecific antibodies with differentiated profiles of cytokine release and biodistribution by CD3 affinity tuning. Sci. Rep. 2021, 11, 14397. [CrossRef] [PubMed]

10. Nouveau, L.; Buatois, V.; Cons, L.; Chatel, L.; Pontini, G.; Pleche, N.; Ferlin, W.G. Immunological analysis of the murine anti-CD3-induced cytokine release syndrome model and therapeutic efficacy of anti-cytokine antibodies. Eur. J. Immunol. 2021, 51, 2074-2085. [CrossRef] [PubMed]

11. Webster, A.C.; Ruster, L.P.; McGee, R.; Matheson, S.L.; Higgins, G.Y.; Willis, N.S.; Chapman, J.R.; Craig, J.C. Interleukin 2 receptor antagonists for kidney transplant recipients. Cochrane Database Syst. Rev. 2010, CD003897. [CrossRef]

12. Chin, C.; Pittson, S.; Luikart, H.; Bernstein, D.; Robbins, R.; Reitz, B.; Oyer, P.; Valantine, H. Induction therapy for pediatric and adult heart transplantation: Comparison between OKT3 and daclizumab. Transplantation 2005, 80, 477-481. [CrossRef] [PubMed]

13. Poire, X.; van Besien, K. Alemtuzumab in allogeneic hematopoetic stem cell transplantation. Expert. Opin. Biol. Ther. 2011, 11, 1099-1111. [CrossRef] [PubMed]

14. Chang, Y.J.; Huang, X.J. Haploidentical stem cell transplantation: Anti-thymocyte globulin-based experience. Semin Hematol. 2016, 53, 82-89. [CrossRef] [PubMed]

15. Huh, J.; Baines, L.; Talbot, D.; MacFie, C. Severe anti-thymocyte globulin-induced cytokine release syndrome in a renal transplant patient. Anaesth. Rep. 2021, 9, 16-19. [CrossRef]

16. Sugita, J. HLA-haploidentical stem cell transplantation using posttransplant cyclophosphamide. Int. J. Hematol. 2019, 110, 30-38. [CrossRef]

17. Kongtim, P.; Ciurea, S.O. Who is the best donor for haploidentical stem cell transplantation? Semin Hematol. 2019, 56, 194-200. [CrossRef] [PubMed]

18. Shabbir-Moosajee, M.; Lombardi, L.; Ciurea, S.O. An overview of conditioning regimens for haploidentical stem cell transplantation with post-transplantation cyclophosphamide. Am. J. Hematol. 2015, 90, 541-548. [CrossRef]

19. Penack, O.; Marchetti, M.; Ruutu, T.; Aljurf, M.; Bacigalupo, A.; Bonifazi, F.; Ciceri, F.; Cornelissen, J.; Malladi, R.; Duarte, R.F.; et al. Prophylaxis and management of graft versus host disease after stem-cell transplantation for haematological malignancies: Updated consensus recommendations of the European Society for Blood and Marrow Transplantation. Lancet Haematol. 2020, 7, e157-e167. [CrossRef]

20. Abboud, R.; Wan, F.; Mariotti, J.; Arango, M.; Castagna, L.; Romee, R.; Hamadani, M.; Chhabra, S. Cytokine release syndrome after haploidentical hematopoietic cell transplantation: An international multicenter analysis. Bone Marrow Transpl. 2021, 56, 1-8. [CrossRef]

21. Abboud, R.; Keller, J.; Slade, M.; DiPersio, J.F.; Westervelt, P.; Rettig, M.P.; Meier, S.; Fehniger, T.A.; Abboud, C.N.; Uy, G.L.; et al. Severe Cytokine-Release Syndrome after T Cell-Replete Peripheral Blood Haploidentical Donor Transplantation Is Associated with Poor Survival and Anti-IL-6 Therapy Is Safe and Well Tolerated. Biol. Blood Marrow Transpl. 2016, 22, 1851-1860. [CrossRef]

22. Salas, M.Q.; Lam, W.; Al-Shaibani, Z.; Viswabandya, A.; Law, A.D. Dual T Cell Depletion with Anti-Thymocyte Globulin and PostTransplant Cyclophosphamide Results in Low Rates of Cytokine Release Syndrome in Peripheral Blood Haplo-Hematopoietic Stem Cell Transplantation. Biol. Blood Marrow Transpl. 2019, 25, e387-e388. [CrossRef] [PubMed] 
23. Gatza, E.; Reddy, P.; Choi, S.W. Prevention and Treatment of Acute Graft-versus-Host Disease in Children, Adolescents, and Young Adults. Biol. Blood Marrow Transpl. 2020, 26, e101-e112. [CrossRef] [PubMed]

24. Teachey, D.T.; Lacey, S.F.; Shaw, P.A.; Melenhorst, J.J.; Maude, S.L.; Frey, N.; Pequignot, E.; Gonzalez, V.E.; Chen, F.; Finklestein, J.; et al. Identification of Predictive Biomarkers for Cytokine Release Syndrome after Chimeric Antigen Receptor T-cell Therapy for Acute Lymphoblastic Leukemia. Cancer Discov. 2016, 6, 664-679. [CrossRef]

25. Giavridis, T.; van der Stegen, S.J.C.; Eyquem, J.; Hamieh, M.; Piersigilli, A.; Sadelain, M. CAR T cell-induced cytokine release syndrome is mediated by macrophages and abated by IL-1 blockade. Nat. Med. 2018, 24, 731-738. [CrossRef] [PubMed]

26. Brudno, J.N.; Kochenderfer, J.N. Recent advances in CAR T-cell toxicity: Mechanisms, manifestations and management. Blood Rev. 2019, 34, 45-55. [CrossRef]

27. Norelli, M.; Camisa, B.; Barbiera, G.; Falcone, L.; Purevdorj, A.; Genua, M.; Sanvito, F.; Ponzoni, M.; Doglioni, C.; Cristofori, P.; et al. Monocyte-derived IL-1 and IL-6 are differentially required for cytokine-release syndrome and neurotoxicity due to CAR T cells. Nat. Med. 2018, 24, 739-748. [CrossRef]

28. Bruserud, O.; Hamann, W.; Patel, S.; Ehninger, G.; Schmidt, H.; Pawelec, G. IFN-gamma and TNF-alpha secretion by CD4+ and CD8+ TCR alpha beta + T-cell clones derived early after allogeneic bone marrow transplantation. Eur. J. Haematol. 1993, 51, 73-79. [CrossRef]

29. Bruserud, O.; Ehninger, G.; Hamann, W.; Pawelec, G. Secretion of IL-2, IL-3, IL-4, IL-6 and GM-CSF by CD4+ and CD8+ TCR alpha beta+ T-cell clones derived early after allogeneic bone marrow transplantation. Scand. J. Immunol. 1993, 38, 65-74. [CrossRef]

30. Bruserud, O.; Hamann, W.; Pawelec, G. Secretion of leukaemia inhibitory factor after allogeneic bone marrow transplantation: A study of CD4+ and CD8+ TCR alpha beta+ T-cell clones derived from four leukaemia patients. Eur. J. Haematol. 1995, 54, 106-110. [CrossRef]

31. Rundgren, I.M.; Bruserud, O.; Ryningen, A.; Ersvaer, E. Standardization of sampling and sample preparation for analysis of human monocyte subsets in peripheral blood. J. Immunol. Methods 2018, 461, 53-62. [CrossRef] [PubMed]

32. Sachdeva, M.; Duchateau, P.; Depil, S.; Poirot, L.; Valton, J. Granulocyte-macrophage colony-stimulating factor inactivation in CAR T-cells prevents monocyte-dependent release of key cytokine release syndrome mediators. J. Biol. Chem. 2019, 294, 5430-5437. [CrossRef]

33. Rundgren, I.M.; Ryningen, A.; Anderson Tvedt, T.H.; Bruserud, O.; Ersvaer, E. Immunomodulatory Drugs Alter the Metabolism and the Extracellular Release of Soluble Mediators by Normal Monocytes. Molecules 2020, 25, 367. [CrossRef]

34. Root-Bernstein, R. Innate Receptor Activation Patterns Involving TLR and NLR Synergisms in COVID-19, ALI/ARDS and Sepsis Cytokine Storms: A Review and Model Making Novel Predictions and Therapeutic Suggestions. Int. J. Mol. Sci. 2021, $22,2108$. [CrossRef] [PubMed]

35. Kumar, V. Toll-like receptors in sepsis-associated cytokine storm and their endogenous negative regulators as future immunomodulatory targets. Int. Immunopharmacol. 2020, 89, 107087. [CrossRef]

36. Brandao, S.C.S.; Ramos, J.O.X.; Dompieri, L.T.; Godoi, E.; Figueiredo, J.L.; Sarinho, E.S.C.; Chelvanambi, S.; Aikawa, M. Is Toll-like receptor 4 involved in the severity of COVID-19 pathology in patients with cardiometabolic comorbidities? Cytokine Growth Factor Rev. 2021, 58, 102-110. [CrossRef]

37. Jung, J.Y.; Kim, J.W.; Suh, C.H.; Kim, H.A. Roles of Interactions Between Toll-Like Receptors and Their Endogenous Ligands in the Pathogenesis of Systemic Juvenile Idiopathic Arthritis and Adult-Onset Still's Disease. Front. Immunol. 2020, $11,583513$. [CrossRef]

38. Lin, M.; Tang, S.C. Toll-like receptors: Sensing and reacting to diabetic injury in the kidney. Nephrol. Dial. Transpl. 2014, 29, 746-754. [CrossRef] [PubMed]

39. Bruserud, O.; Reikvam, H. Therapeutic targeting of NF-kappaB in myelodysplastic syndromes and acute myeloid leukaemia-The biological heterogeneity. Expert. Opin. Ther. Targets 2010, 14, 1139-1142. [CrossRef]

40. Ogonek, J.; Kralj Juric, M.; Ghimire, S.; Varanasi, P.R.; Holler, E.; Greinix, H.; Weissinger, E. Immune Reconstitution after Allogeneic Hematopoietic Stem Cell Transplantation. Front. Immunol. 2016, 7, 507. [CrossRef] [PubMed]

41. Rundgren, I.M.; Ersvaer, E.; Ahmed, A.B.; Ryningen, A.; Bruserud, O. Circulating monocyte subsets in multiple myeloma patients receiving autologous stem cell transplantation-A study of the preconditioning status and the course until posttransplant reconstitution for a consecutive group of patients. BMC Immunol. 2019, 20, 39. [CrossRef]

42. Davila, M.L.; Riviere, I.; Wang, X.; Bartido, S.; Park, J.; Curran, K.; Chung, S.S.; Stefanski, J.; Borquez-Ojeda, O.; Olszewska, M.; et al. Efficacy and toxicity management of 19-28z CAR T cell therapy in B cell acute lymphoblastic leukemia. Sci. Transl. Med. 2014, 6, 224ra225. [CrossRef] [PubMed]

43. Gust, J.; Finney, O.C.; Li, D.; Brakke, H.M.; Hicks, R.M.; Futrell, R.B.; Gamble, D.N.; Rawlings-Rhea, S.D.; Khalatbari, H.K.; Ishak, G.E.; et al. Glial injury in neurotoxicity after pediatric CD19-directed chimeric antigen receptor T cell therapy. Ann. Neurol. 2019, 86, 42-54. [CrossRef]

44. Brentjens, R.J.; Davila, M.L.; Riviere, I.; Park, J.; Wang, X.; Cowell, L.G.; Bartido, S.; Stefanski, J.; Taylor, C.; Olszewska, M.; et al. CD19-targeted $\mathrm{T}$ cells rapidly induce molecular remissions in adults with chemotherapy-refractory acute lymphoblastic leukemia. Sci. Transl. Med. 2013, 5, 177ra138. [CrossRef] [PubMed]

45. Kochenderfer, J.N.; Dudley, M.E.; Feldman, S.A.; Wilson, W.H.; Spaner, D.E.; Maric, I.; Stetler-Stevenson, M.; Phan, G.Q.; Hughes, M.S.; Sherry, R.M.; et al. B-cell depletion and remissions of malignancy along with cytokine-associated toxicity in a clinical trial of anti-CD19 chimeric-antigen-receptor-transduced T cells. Blood 2012, 119, 2709-2720. [CrossRef] [PubMed] 
46. Obstfeld, A.E.; Frey, N.V.; Mansfield, K.; Lacey, S.F.; June, C.H.; Porter, D.L.; Melenhorst, J.J.; Wasik, M.A. Cytokine release syndrome associated with chimeric-antigen receptor T-cell therapy: Clinicopathological insights. Blood 2017, 130, $2569-2572$. [CrossRef]

47. Bruserud, O.; Aarstad, H.H.; Tvedt, T.H.A. Combined C-Reactive Protein and Novel Inflammatory Parameters as a Predictor in Cancer-What Can We Learn from the Hematological Experience? Cancers 2020, 12, 1966. [CrossRef] [PubMed]

48. Melody, M.; Rahman, Z.A.; Saunders, H.; Diaz, P.L.; Gannon, N.; Rosenthal, A.; Ayala, E.; Tun, H.W.; Murthy, H.; Roy, V.; et al. C-reactive protein and ferritin levels and length of intensive care unit stay in patients with B-cell lymphomas treated with axicabtagene ciloleucel. Hematol. Oncol. Stem. Cell. Ther. 2021, 14, 141-146. [CrossRef]

49. Karschnia, P.; Jordan, J.T.; Forst, D.A.; Arrillaga-Romany, I.C.; Batchelor, T.T.; Baehring, J.M.; Clement, N.F.; Gonzalez Castro, L.N.; Herlopian, A.; Maus, M.V.; et al. Clinical presentation, management, and biomarkers of neurotoxicity after adoptive immunotherapy with CAR T cells. Blood 2019, 133, 2212-2221. [CrossRef]

50. Sandnes, M.; Ulvik, R.J.; Vorland, M.; Reikvam, H. Hyperferritinemia-A Clinical Overview. J. Clin. Med. 2021, 10, 2008. [CrossRef]

51. Brentjens, R.; Yeh, R.; Bernal, Y.; Riviere, I.; Sadelain, M. Treatment of chronic lymphocytic leukemia with genetically targeted autologous T cells: Case report of an unforeseen adverse event in a phase I clinical trial. Mol. Ther. 2010, 18, 666-668. [CrossRef] [PubMed]

52. Li, N.; Li, H. Effect of anti-CD19 chimeric antigen receptor T cell therapy in children with relapsed or refractory acute Blymphocytic leukemia and its prognosis. J. BUON 2021, 26, 159-165. [PubMed]

53. Greenbaum, U.; Strati, P.; Saliba, R.M.; Torres, J.; Rondon, G.; Nieto, Y.; Hosing, C.; Srour, S.A.; Westin, J.; Fayad, L.E.; et al. CRP and ferritin in addition to the EASIX score predict CAR-T-related toxicity. Blood Adv. 2021, 5, 2799-2806. [CrossRef] [PubMed]

54. Reikvam, H.; Hatfield, K.J.; Fredly, H.; Nepstad, I.; Mosevoll, K.A.; Bruserud, O. The angioregulatory cytokine network in human acute myeloid leukemia-From leukemogenesis via remission induction to stem cell transplantation. Eur. Cytokine Netw. 2012, 23, 140-153. [CrossRef] [PubMed]

55. Kotch, C.; Barrett, D.; Teachey, D.T. Tocilizumab for the treatment of chimeric antigen receptor T cell-induced cytokine release syndrome. Expert. Rev. Clin. Immunol. 2019, 15, 813-822. [CrossRef] [PubMed]

56. Nishimoto, N.; Kishimoto, T. Humanized antihuman IL-6 receptor antibody, tocilizumab. Handb. Exp. Pharmacol. 2008, 10, 151-160. [CrossRef]

57. Tanaka, T.; Narazaki, M.; Kishimoto, T. Immunotherapeutic implications of IL-6 blockade for cytokine storm. Immunotherapy 2016, 8, 959-970. [CrossRef]

58. Hunter, C.A.; Jones, S.A. IL-6 as a keystone cytokine in health and disease. Nat. Immunol. 2015, 16, 448-457. [CrossRef]

59. Pathan, N.; Hemingway, C.A.; Alizadeh, A.A.; Stephens, A.C.; Boldrick, J.C.; Oragui, E.E.; McCabe, C.; Welch, S.B.; Whitney, A.; O'Gara, P.; et al. Role of interleukin 6 in myocardial dysfunction of meningococcal septic shock. Lancet 2004, 363, 203-209. [CrossRef]

60. Gordon, J.S.; Drazner, M.H. Biomarkers of Cardiac Stress and Cytokine Release Syndrome in COVID-19: A Review. Curr. Heart Fail. Rep. 2021, 18, 163-168. [CrossRef]

61. Wang, Z.; Han, W. Biomarkers of cytokine release syndrome and neurotoxicity related to CAR-T cell therapy. Biomark Res. 2018, 6, 4. [CrossRef]

62. Reikvam, H.; Gronningsaeter, I.S.; Ahmed, A.B.; Hatfield, K.; Bruserud, O. Metabolic Serum Profiles for Patients Receiving Allogeneic Stem Cell Transplantation: The Pretransplant Profile Differs for Patients with and without Posttransplant Capillary Leak Syndrome. Dis. Markers 2015, 2015, 943430. [CrossRef]

63. Ricklin, D.; Barratt-Due, A.; Mollnes, T.E. Complement in clinical medicine: Clinical trials, case reports and therapy monitoring. Mol. Immunol. 2017, 89, 10-21. [CrossRef] [PubMed]

64. Howard, S.C.; Jones, D.P.; Pui, C.H. The tumor lysis syndrome. N. Engl. J. Med. 2011, 364, 1844-1854. [CrossRef] [PubMed]

65. Biswas, S.K.; Mantovani, A. Macrophage plasticity and interaction with lymphocyte subsets: Cancer as a paradigm. Nat. Immunol. 2010, 11, 889-896. [CrossRef]

66. Mantovani, A.; Garlanda, C.; Locati, M. Macrophage diversity and polarization in atherosclerosis: A question of balance. Arter. Thromb. Vasc. Biol. 2009, 29, 1419-1423. [CrossRef] [PubMed]

67. Bethell, D.B.; Flobbe, K.; Cao, X.T.; Day, N.P.; Pham, T.P.; Buurman, W.A.; Cardosa, M.J.; White, N.J.; Kwiatkowski, D. Pathophysiologic and prognostic role of cytokines in dengue hemorrhagic fever. J. Infect. Dis. 1998, 177, 778-782. [CrossRef]

68. Bruserud, O.; Halstensen, A.; Peen, E.; Solberg, C.O. Serum levels of adhesion molecules and cytokines in patients with acute leukaemia. Leuk Lymphoma 1996, 23, 423-430. [CrossRef]

69. Mosevoll, K.A.; Johansen, S.; Wendelbo, O.; Nepstad, I.; Bruserud, O.; Reikvam, H. Cytokines, Adhesion Molecules, and Matrix Metalloproteases as Predisposing, Diagnostic, and Prognostic Factors in Venous Thrombosis. Front. Med. (Lausanne) $2018,5,147$. [CrossRef] [PubMed]

70. Bruserud, O.; Akselen, P.E.; Bergheim, J.; Nesthus, I. Serum concentrations of E-selectin, P-selectin, ICAM-1 and interleukin 6 in acute leukaemia patients with chemotherapy-induced leucopenia and bacterial infections. Br. J. Haematol. 1995, 91, 394-402. [CrossRef]

71. Aarstad, H.H.; Moe, S.E.E.; Bruserud, O.; Lybak, S.; Aarstad, H.J.; Tvedt, T.H.A. The Acute Phase Reaction and Its Prognostic Impact in Patients with Head and Neck Squamous Cell Carcinoma: Single Biomarkers Including C-Reactive Protein Versus Biomarker Profiles. Biomedicines 2020, 8, 418. [CrossRef] [PubMed] 
72. Aarstad, H.H.; Guethbrandsdottir, G.; Hjelle, K.M.; Bostad, L.; Bruserud, O.; Tvedt, T.H.A.; Beisland, C. The Biological Context of C-Reactive Protein as a Prognostic Marker in Renal Cell Carcinoma: Studies on the Acute Phase Cytokine Profile. Cancers 2020, 12, 1961. [CrossRef] [PubMed]

73. Lee, D.W.; Gardner, R.; Porter, D.L.; Louis, C.U.; Ahmed, N.; Jensen, M.; Grupp, S.A.; Mackall, C.L. Current concepts in the diagnosis and management of cytokine release syndrome. Blood 2014, 124, 188-195. [CrossRef]

74. Lee, D.W.; Santomasso, B.D.; Locke, F.L.; Ghobadi, A.; Turtle, C.J.; Brudno, J.N.; Maus, M.V.; Park, J.H.; Mead, E.; Pavletic, S.; et al. ASTCT Consensus Grading for Cytokine Release Syndrome and Neurologic Toxicity Associated with Immune Effector Cells. Biol. Blood Marrow Transpl. 2019, 25, 625-638. [CrossRef]

75. Herrmann, J. Adverse cardiac effects of cancer therapies: Cardiotoxicity and arrhythmia. Nat. Rev. Cardiol. 2020, 17, 474-502. [CrossRef] [PubMed]

76. Hansen, B.A.; Wendelbo, O.; Bruserud, O.; Hemsing, A.L.; Mosevoll, K.A.; Reikvam, H. Febrile Neutropenia in Acute Leukemia. Epidemiology, Etiology, Pathophysiology and Treatment. Mediterr. J. Hematol. Infect. Dis. 2020, 12, e2020009. [CrossRef]

77. Marsh, R.A.; Haddad, E. How i treat primary haemophagocytic lymphohistiocytosis. Br. J. Haematol. 2018, 182, 185-199. [CrossRef] [PubMed]

78. Melve, G.K.; Ersvssr, E.; Kittang, A.O.; Bruserud, O. The chemokine system in allogeneic stem-cell transplantation: A possible therapeutic target? Expert. Rev. Hematol. 2011, 4, 563-576. [CrossRef]

79. Muller, L.; Di Benedetto, S.; Pawelec, G. The Immune System and Its Dysregulation with Aging. Subcell Biochem. 2019, 91, 21-43. [CrossRef]

80. Tvedt, T.H.; Lie, S.A.; Reikvam, H.; Rye, K.P.; Lindas, R.; Gedde-Dahl, T.; Ahmed, A.B.; Bruserud, O. Pretransplant Levels of CRP and Interleukin-6 Family Cytokines; Effects on Outcome after Allogeneic Stem Cell Transplantation. Int. J. Mol. Sci. 2016, 17, 1823. [CrossRef]

81. Solan, L.; Landete, E.; Bailen, R.; Dorado, N.; Oarbeascoa, G.; Anguita, J.; Diez-Martin, J.L.; Kwon, M. Cytokine release syndrome after allogeneic stem cell transplantation with posttransplant cyclophosphamide. Hematol. Oncol. 2020, 38, 597-603. [CrossRef] [PubMed]

82. Shimabukuro-Vornhagen, A.; Godel, P.; Subklewe, M.; Stemmler, H.J.; Schlosser, H.A.; Schlaak, M.; Kochanek, M.; Boll, B.; von Bergwelt-Baildon, M.S. Cytokine release syndrome. J. Immunother. Cancer 2018, 6, 56. [CrossRef] [PubMed]

83. Mitchell, C.D.; Richards, S.M.; Kinsey, S.E.; Lilleyman, J.; Vora, A.; Eden, T.O.; The Medical Research Council Childhood Leukaemia Working Party. Benefit of dexamethasone compared with prednisolone for childhood acute lymphoblastic leukaemia: Results of the UK Medical Research Council ALL97 randomized trial. Br. J. Haematol. 2005, 129, 734-745. [CrossRef] [PubMed]

84. Koller, G.M.; Schafer, C.; Kemp, S.S.; Aguera, K.N.; Lin, P.K.; Forgy, J.C.; Griffin, C.T.; Davis, G.E. Proinflammatory Mediators, IL (Interleukin)-1beta, TNF (Tumor Necrosis Factor) alpha, and Thrombin Directly Induce Capillary Tube Regression. Arter. Thromb. Vasc. Biol. 2020, 40, 365-377. [CrossRef]

85. Blecharz-Lang, K.G.; Wagner, J.; Fries, A.; Nieminen-Kelha, M.; Rosner, J.; Schneider, U.C.; Vajkoczy, P. Interleukin 6-Mediated Endothelial Barrier Disturbances Can Be Attenuated by Blockade of the IL6 Receptor Expressed in Brain Microvascular Endothelial Cells. Transl. Stroke Res. 2018, 9, 631-642. [CrossRef]

86. Ridiandries, A.; Tan, J.T.; Bursill, C.A. The Role of CC-Chemokines in the Regulation of Angiogenesis. Int. J. Mol. Sci. 2016, 17, 1856. [CrossRef]

87. Reikvam, H.; Nepstad, I.; Bruserud, O.; Hatfield, K.J. Pharmacological targeting of the PI3K/mTOR pathway alters the release of angioregulatory mediators both from primary human acute myeloid leukemia cells and their neighboring stromal cells. Oncotarget 2013, 4, 830-843. [CrossRef] [PubMed]

88. Billiau, A.D.; Roskams, T.; Van Damme-Lombaerts, R.; Matthys, P.; Wouters, C. Macrophage activation syndrome: Characteristic findings on liver biopsy illustrating the key role of activated, IFN-gamma-producing lymphocytes and IL-6- and TNF-alphaproducing macrophages. Blood 2005, 105, 1648-1651. [CrossRef]

89. Kantarjian, H.; Stein, A.; Gokbuget, N.; Fielding, A.K.; Schuh, A.C.; Ribera, J.M.; Wei, A.; Dombret, H.; Foa, R.; Bassan, R.; et al. Blinatumomab versus Chemotherapy for Advanced Acute Lymphoblastic Leukemia. N. Engl. J. Med. 2017, 376, 836-847. [CrossRef]

90. Cifaldi, L.; Prencipe, G.; Caiello, I.; Bracaglia, C.; Locatelli, F.; De Benedetti, F.; Strippoli, R. Inhibition of natural killer cell cytotoxicity by interleukin-6: Implications for the pathogenesis of macrophage activation syndrome. Arthritis Rheumatol. 2015, 67, 3037-3046. [CrossRef] [PubMed]

91. Greco, R.; Lorentino, F.; Nitti, R.; Lupo Stanghellini, M.T.; Giglio, F.; Clerici, D.; Xue, E.; Lazzari, L.; Piemontese, S.; Mastaglio, S.; et al. Interleukin-6 as Biomarker for Acute GvHD and Survival After Allogeneic Transplant With Post-transplant Cyclophosphamide. Front. Immunol. 2019, 10, 2319. [CrossRef] [PubMed]

92. Imus, P.H.; Blackford, A.L.; Bettinotti, M.; Luznik, L.; Fuchs, E.J.; Huff, C.A.; Gladstone, D.E.; Ambinder, R.F.; Borrello, I.M.; Fuchs, R.J.; et al. Severe Cytokine Release Syndrome after Haploidentical Peripheral Blood Stem Cell Transplantation. Biol. Blood Marrow Transpl. 2019, 25, 2431-2437. [CrossRef] [PubMed]

93. Wang, X.S.; Srour, S.A.; Whisenant, M.; Subbiah, I.; Chen, T.H.; Ponce, D.; Gonzalez, A.G.; Kamal, M.; Mendoza, T.; Cleland, C.; et al. Patient-Reported Symptom and Functioning Status during the First 12 Months after Chimeric Antigen Receptor T Cell Therapy for Hematologic Malignancies. Transpl. Cell Ther. 2021, 27, 930.e1-930.e10. [CrossRef] [PubMed] 